\title{
CANNALICULAR OCCLUSION WITH CYANOACRYLATE ADHESIVE: A NEW TREATMENT FOR THE DRY EYE
}

\author{
JEREMY P. DIAMOND ${ }^{1}$, JAMES E. MORGAN ${ }^{1}$, JIM VIRJEE $^{2}$ and DAVID L. EASTY ${ }^{1}$ \\ Bristol
}

\begin{abstract}
SUMMARY
One hundred microlitres $(0.1 \mathrm{ml})$ of $\mathrm{N}$-butyl cyanoacrylate adhesive was injected into the inferior cannaliculus of 8 patients with dry eye. The adhesive induced total (upper and lower) cannalicular occlusion in each patient which has not resolved to date (mean follow-up 15.2 months, range 11-19 months). Complications were minor and not specific to use of this adhesive. It is hoped that its ultimate reversibility will make the technique suitable for younger patients with dry eye.
\end{abstract}

Lacrimal cannalicular (punctal) occlusion is used in the treatment of dry eye with the intention of preserving the natural tears and prolonging the effect of artificial wetting agents. ${ }^{1}$ The cannaliculae may be occluded temporarily or permanently. Permanent block is reserved for patients with poor prognosis for recovery of lacrimal gland function while temporary occlusion is applicable if improvement is considered possible. Although many young patients with dry eye require long-term treatment, permanent occlusion is rarely undertaken to avoid risk of inducing late-onset epiphora. In consequence there is justification to investigate potential extended, reversible cannalicular occlusive techniques.

\section{PATHENTS AND METHODS}

Patients attending the Bristol Eye Hospital were recruited into the study if they had signs and symptoms of keratoconjunctivitis sicca (KCS), were aged over 50 years, had no previous lid or lacrimal surgery and had normal lids and lacrimal punctae on

From: 'University of Bristol, Department of Ophthalmology, Bristol Eye Hospital: ${ }^{2}$ Department of Radiology, Bristol Royal Infirmary. Bristol, UK

Correspondence to: Jeremy P. Diamond, FRCS, FRCOphth, University of Bristol. Department of Ophthalmology, Bristol Eye Hospital, Lower Maudlin Street. Bristol BS2 2LX, UK. slit lamp examination. Dry eye was diagnosed objectively on the basis of reduced filter-paper wetting (less than $5 \mathrm{~mm}$ after 5 minutes) and subjectively by evaluation of the marginal tear meniscus. All patients were counselled with respect to their condition and the treatment options available. They were subsequently given an information sheet pertaining to the trial. The study had local ethics committee approval.

For each patient, unaided, corrected and pin-hole Snellen visual acuity was recorded and corneal and conjunctival morphology assessed using flourescein dye. A questionnaire was used to quantify the degree of discomfort related to the dry eye condition.

Prior to inclusion in the study, patients had a baseline assessment of tear drainage using dacryoscintigraphy: a single drop $(0.1 \mathrm{ml})$ of sodium pertechnate containing 4 megabequerels of radioactivity was applied to the inferior fornix and serial scans performed every 6 seconds for 10 minutes with a computer-linked gamma camera. ${ }^{2}$ Lacrimal drainage was assessed in terms of isotope transit time $(\mathrm{tt})$ into the nasolacrimal duct (NLD). Only patients with normal tear drainage (defined as an NLD-tt below 10 minutes) were enrolled (Fig. 1).

The last 7 patients received superior and inferior punctal gelatin plugs to exclude the risk of epiphora associated with cannalicular block.

Each patient received topical anaesthesia and the inferior punctum was dilated using a Nettleship dilator sufficient to gain access with a lacrimal cannula. One hundred microlitres $(0.1 \mathrm{ml})$ of $N$ butyl cyanoacrylate adhesive (Histoacryl-blau, B Braun Melsungen AG) was drawn up via a 25 gauge needle into a $1 \mathrm{ml}$ syringe (cadaver studies having indicated that $0.1 \mathrm{ml}$ of adhesive would adequately fill the cannaliculus between the punctum and the entrance to the lacrimal sac (Fig. 2). The needle was replaced with a disposable lacrimal cannula which was inserted into the inferior 


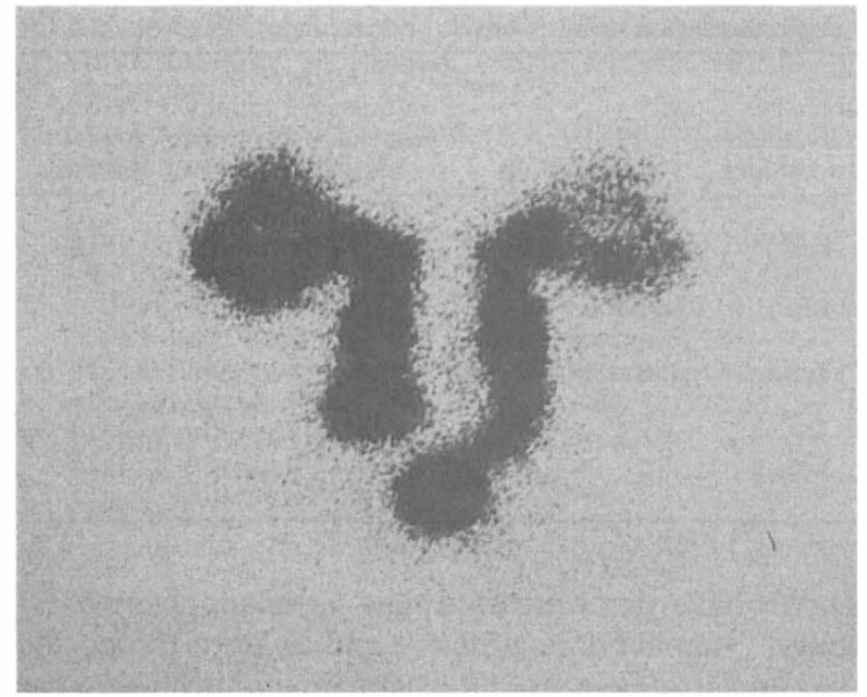

Fig. 1. Pre-occlusion scintigram showing passage of isotope down the left lacrimal cannaliculi, 15 minutes after instillation of isotope.

punctum. Pressure was applied over the lacrimal fossa with the index finger to limit passage of adhesive into the lacrimal sac during injection. Any adhesive protruding out of the punctum after polymerisation was trimmed with scissors. If adhesive refluxed through the upper punctum onto the cornea or conjunctiva it could easily be removed when dry with a cotton-tipped applicator. Adhesive was stored at $4{ }^{\circ} \mathrm{C}$ for several weeks allowing multiple patients to be treated with one vial, thereby reducing the unit cost of each procedure.

Repeat dacryoscintigraphy within 1 month confirmed that the cannaliculi were occluded (indicated by a nasolacrimal duct transit time greater than 10 minutes: Fig. 3). Thereafter, the patient was instructed to continue wetting agents as required

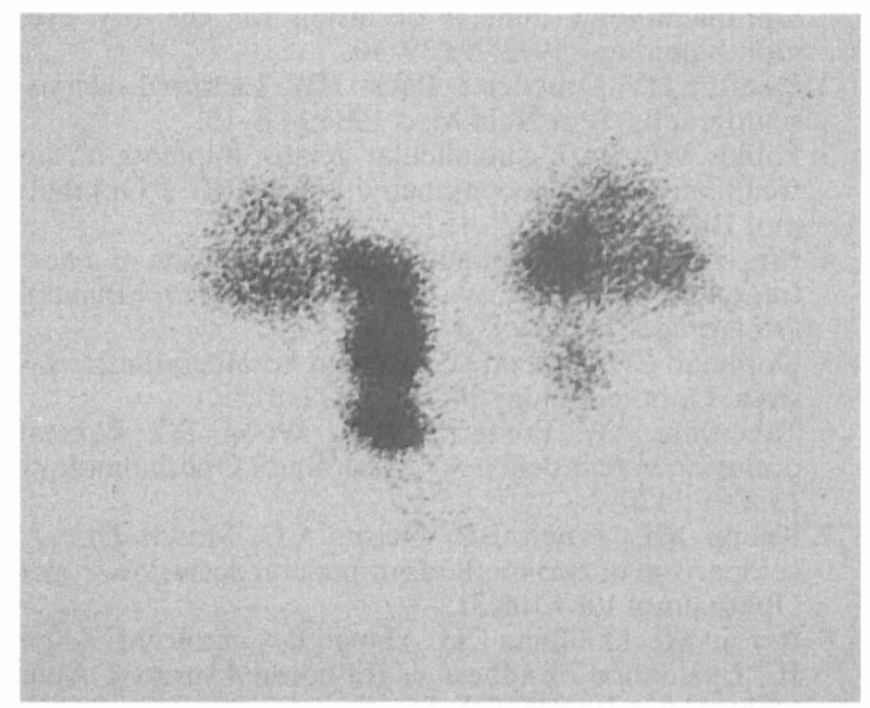

Fig. 3. Post-injection scintigram demonstrating total occlusion of the left cannaliculi, 30 minutes after instillation of isotope.

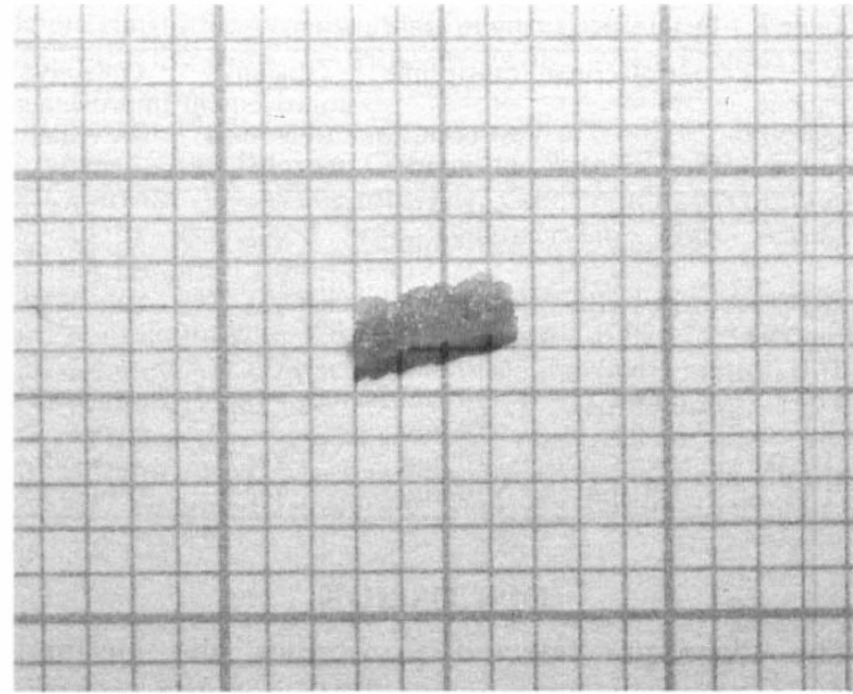

Fig. 2. Cyanoacrylate plug (on a millimetre grid) removed from cadaver.

and was reviewed monthly. At each subsequent visit, visual acuity and external eye morphology were recorded and a questionnaire completed to quantify subjective benefits or complications of the adhesive. Repeat dacryoscintigraphy was undertaken at intervals during follow-up.

\section{RESULTS}

A total of 8 patients received intracannalicular $\mathrm{N}$ butyl cyanoacrylate adhesive, of whom 7 (87.5\%) were female and $1(12.5 \%)$ male. Mean age was 68 years (range 61-73 years). Follow-up ranged from 11 to 19 months (mean 15.2 months). Each patient demonstrated radiological evidence of total cannalicular obstruction within the first month following application.

The complications of the procedure were minor. Two patients $(25.0 \%)$ complained of irritation immediately following adhesive application. Examination in each case demonstrated a small spicule of dry adhesive protruding out of the inferior punctum and contacting the cornea. In each case the glue was trimmed with scissors and no further discomfort was noted. One patient $(12.5 \%)$ complained of epiphora which has lasted for 19 months after adhesive application. One patient $(12.5 \%)$ had a protracted episode of cannaliculitis (approximately 3 weeks duration) requiring topical antibiotic treatment.

Data pertaining to patient age, objective and subjective benefit derived from occlusion, incidence of complications and length of follow-up are shown in Table I.

Repeat dacryoscintigraphy has been performed on all patients between 10 and 19 months after application of the glue. No patients have demonstrated radiological evidence of re-canalisation to date. 
Table I. Details pertaining to eight patients receiving unilateral cannalicular occlusion using $N$-butyl cyanoacrylate adhesive

\begin{tabular}{|c|c|c|c|c|c|c|c|c|}
\hline \multirow[b]{2}{*}{$\begin{array}{l}\text { Patient } \\
\text { age (yr) } \\
\text { and sex }\end{array}$} & \multicolumn{2}{|c|}{ Nasolacrimal transit time } & \multirow{2}{*}{$\begin{array}{c}\text { Objective } \\
\text { - improvement } \\
\text { in corneal } \\
\text { morphology }\end{array}$} & \multirow{2}{*}{$\begin{array}{l}\text { Objective } \\
\text { improvement } \\
\text { in visual } \\
\text { acuity }\end{array}$} & \multirow{2}{*}{$\begin{array}{l}\text { Subjective } \\
\text { improvement } \\
\text { in discomfort }\end{array}$} & \multirow[b]{2}{*}{ Complications } & \multirow{2}{*}{$\begin{array}{c}\text { Delayed } \\
\text { dacryoscintigraphy } \\
\text { (nasolacrimal transit } \\
\text { time/follow-up) }\end{array}$} & \multirow[b]{2}{*}{$\begin{array}{c}\text { Total } \\
\text { follow-up } \\
\text { (months) }\end{array}$} \\
\hline & Pre-occlusion & $\begin{array}{l}\text { Post-occlusion } \\
(1 \text { month })\end{array}$ & & & & & & \\
\hline $72 \mathrm{~F}$ & $<6 s$ & $>10 \min$ & - & - & - & Epiphora & $>10 \mathrm{~min} / 19$ months & 20 \\
\hline $69 \mathrm{~F}$ & $<6 s$ & $>10 \mathrm{~min}$ & Yes & - & Yes & $\begin{array}{l}\text { Irrigation after } \\
\text { application }\end{array}$ & $>10 \mathrm{~min} / 17$ months & 18 \\
\hline $73 \mathrm{~F}$ & $<6 \mathrm{~s}$ & $>10 \mathrm{~min}$ & Yes & $6 / 36-6 / 18$ & Yes & $\begin{array}{l}\text { Irritation after } \\
\text { application }\end{array}$ & $>10 \mathrm{~min} / 16$ months & 17 \\
\hline $64 \mathrm{~F}$ & $<6 s$ & $>10 \mathrm{~min}$ & Yes & - & Yes & Cannaliculitis & $>10 \mathrm{~min} / 15$ months & 16 \\
\hline $66 \mathrm{~F}$ & $<6 s$ & $>10 \min$ & - & - & - & - & $>10 \mathrm{~min} / 14$ months & 15 \\
\hline $69 \mathrm{~F}$ & $<6 s$ & $>10 \mathrm{~min}$ & - & - & - & - & $>10 \mathrm{~min} / 13 \mathrm{months}$ & 14 \\
\hline $61 \mathrm{~F}$ & $<6 s$ & $>10 \mathrm{~min}$ & Yes & $6 / 6-6 / 5$ & Yes & - & $>10 \mathrm{~min} / 10 \mathrm{months}$ & 11 \\
\hline $71 \mathrm{M}$ & $9 \min$ & $>10 \min$ & Yes & $6 / 18-6 / 12$ & - & - & $>10 \mathrm{~min} / 10$ months & 11 \\
\hline
\end{tabular}

\section{DISCUSSION}

The technique selected to occlude the lacrimal drainage apparatus is dependent upon the severity of the dry eye, the age of the patient and the prognosis of resolution of condition.

Several techniques can achieve temporary punctal occlusion. Gelatin rods are cheap, easy to insert and well tolerated by the patient. ${ }^{3}$ Unfortunately they rarely induce total cannalicular occlusion for more than a few days and their use is now limited to evaluating the role of subsequent longer-term occlusive procedures. Silicon punctal plugs are designed to stay in place until removed by the surgeon. ${ }^{4}$ Unfortunately they are expensive and in our experience can be difficult to implant, uncomfortable for the patient and may be dislodged or removed accidentally.

Permanent punctal occlusion is generally reserved for older patients who are deemed to have a poor prognosis for resolution of the condition. It can be procured using cautery combined with an encircling dissolvable suture. ${ }^{5-7}$ Argon laser 'punctoplasty' has also been proposed. ${ }^{1}$

Cyanoacrylate adhesives were first applied in ophthalmology in the mid-1960s in treatment of corneal dehiscence ${ }^{8,9}$ and are widely used for closure of aqueous leaks following trauma, spontaneous corneal melting and surgery. ${ }^{10-12}$. They have also been reported to be valuable in the management of retinal detachment, ${ }^{13}$ in securing orbital implants, ${ }^{14}$ for procuring temporary tarsorrhaphy ${ }^{15}$ and for removal of intraocular lenses. ${ }^{16}$ Cyanoacrylate adhesives have also been used to obtain temporary punctal occlusion. ${ }^{17}$ However, in this report a drop of adhesive was applied directly to the punctum which only achieved a short-term block (mean 2.5 weeks).

Cyanoacrylate adhesives are generally well tolerated by biological tissues. Reported side-effects include giant papillary conjunctivitis, ${ }^{18}$ contact dermatitis $^{19}$ and symblepharon formation. ${ }^{20}$ The short side-chain derivatives (ethyl and methyl cyanoacrylate), commonly available as 'superglues', are reported to be more toxic than the $N$-butyl cyanoacrylate in medical use. ${ }^{21}$
We have demonstrated that intracannalicular $\mathrm{N}$ butyl cyanoacrylate adhesive can be used to occlude lacrimal drainage. To date, cannalicular occlusion has lasted for up to 19 months without evidence of spontaneous re-canalisation. Total follow-up has extended over 121 patient-months during which period no significant complications have occurred.

It is hoped that ultimate re-canalisation will extend the application of this technique to younger patients with dry eye. To this end we shall undertake further scintigraphy upon these patients in the future. At present, however, although safe and easy to apply, cyanoacrylate punctal occlusion can only be recommended for those patients requiring permanent punctal occlusion.

We should like to thank Mr S. D. Cook, Mr M. J. Potts and $\mathrm{Mr}$ R. H. B. Grey for allowing us to treat their patients, and Mrs Gill Benerson for the photography.

Key words: Cannalicular occlusion, Cyanoacrylate, Dry eye, Punctal occlusion.

\section{REFERENCES}

1. Information Statement from American Academy of Ophthalmology. Punctal occlusion for the dry eye. Ophthalmology 1992;99:639-40.

2. Denffer HV, Dressler J, Pabst HW. Lacrimal dacryoscintigraphy. Sem Nucl Med 1984;14:8-15.

3. Foulds WS. Intra-cannalicular gelatin implants in the treatment of keratoconjunctivitis sicca. Br J Ophthalmol 1961;45:625-7.

4. Freeman JMM. The punctum plug: evaluation of a new treatment for the dry eye. Trans Am Acad Ophthalmol Otolaryngol 1975;79:874-9.

5. Dohlman CH. Punctal occlusion in keratoconjunctivitis sicca. Ophthalmology 1978;85:1277-81.

6. Tuberville AW, Frederick WR, Wood TO. Punctal occlusion in tear deficiency syndromes. Ophthalmology 1982;89:1170-2.

7. Knapp ME, Frueh BR, Nelson CC, Musch DC. A comparison of two methods of punctal occlusion. Am J Ophthalmol 1989:108:315-8.

8. Refojo MF, Dohlman CH, Ahmad B, Carroll JM, Allen JC. Evaluation of adhesives for corneal surgery. Arch Ophthalmol 1968;80:645-56.

9. Schimek RA, Ballow GS. Eastman 910 Monomer for plastic lid procedures. Am J Ophthalmol 1966; 62:953-5. 
10. Refojo MF, Dohlman CH, Koliopoulos J. Adhesives in ophthalmology: a review. Surv Ophthamol 1971; 15:217-36.

11. Streit S, Ackerman J, Kanarek I. Cyanoacrylate. Ann Ophthalmol 1981;13:315-6.

12. Leahey AB, Gottsh JD, Stark WJ. Clinical experience with $N$-butyl-cyanoacrylate (Nexacryl) tissue adhesive. Ophthalmology 1993;100:173-80.

13. Folk JC, Dreyer RF. Cyanoacrylate adhesive in retinal detachment surgery. Am J Ophthalmol 1986;101:486-7.

14. Tse DT. Cyanoacrylate tissue adhesives in securing orbital implants. Ophthalmic Surg 1986;17:577-80.

15. Diamond JP. Temporary tarsorrhaphy with cyanoacrylate adhesive for seventh nerve palsy. Lancet 1990;335:1039.

16. DeGuillebon H, Zauberman H, Refojo MF. Cyanoa- crylate adhesive: use in the removal of lens and foreign particles from the vitreous cavity. Arch Ophthalmol 1972;87:407-10.

17. Patten JT. Punctal occlusion with $N$-butyl-cyanoacrylate tissue adhesive. Ophthalmic Surg 1976;7:24-6.

18. Carlson AN, Wilhelmus KR. Giant papillary conjunctivitis associated with cyanoacrylate glue. Am J Ophthalmol 1987;104:437-78.

19. Belsito DV. Contact dermatitis to ethyl cyanoacrylate containing glue. Contact Dermatitis 1987;17:234-6.

20. Leahey AB, Gottsch JD. Symblepharon formation with cyanoacrylate adhesive. Arch Ophthalmol 1993; 111:168.

21. Allaforr RM. Most cyanoacrylate super-glues should be removed promptly [letter]. Ophthalmic Surg 1987;18:156. 